\title{
Landform classification using topography position index (case study: salt dome of Korsia-Darab plain, Iran)
}

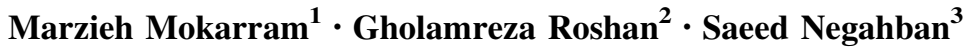

Received: 22 July 2015/Accepted: 7 November 2015/Published online: 19 November 2015

(C) Springer International Publishing Switzerland 2015

\begin{abstract}
In the research aim is to evaluate the Jennes algorithm for landform classification in salt dome of Korsia of Darab plain, Iran. The Jennes's approach uses a multi-scale approach by fitting a quadratic polynomial to a given window size using least squares. In the study used window size of $3 * 3$ and $10 * 10$. Input data for landform classification is digital elevation model (DEM) with resolution of $30 \mathrm{~m}$. After prepared landform classification map for the study area, used geology map. The results show that the evaluated method can be helpful in the predictive mapping of geology. The algorithm of landforms classification proposed by Jennes seem to be the most applicable method.
\end{abstract}

Keywords Landform classification - Jennes algorithms . Digital elevation model $\cdot$ Salt dome of Korsia

Gholamreza Roshan

r.rowshan@yahoo.com

Marzieh Mokarram

m.mokarram@shirazu.ac.ir

Saeed Negahban

snegahban@shirazu.ac.ir

1 Department of Range and Watershed Management, College of Agriculture and Natural Resources of Darab, Shiraz University, Shiraz, Iran

2 Department of Geography, Golestan University, Gorgan, Iran

3 Department of Geography, Shiraz University, Shiraz, Iran

\section{Introduction}

Advances in computer technology, new spatial analytical methods and the increasing availability of digital elevation data have re-oriented geomorphometry (Pike 1999) and promoted the development of computer algorithms for calculating geomorphometric properties of the Earth's surface. In the past, geomorphometric properties have been measured by calculating the geometry of the landscape manually that can be time consuming (Horton 1945; Mokarram 2015; Coates 1958). In the 1960s and early 1970s, the generally availability of computers made possible more complex, statistically-based methods to identify landscape features (Evans 1972; Chorley 1972).

Several papers document applicability of landform classification and relationship with mapping of soil especially in steep land areas (Schmidt and Hewitt 2004). There are new opportunities in this field, resulting from existence of relatively precise global and regional digital elevation models (Meybeck et al. 2001). However, the terms and methods used in different fields of science vary in detail (Barka 2009; MacMillan et al. 2000; Ratajczak and Jasiewicz 2009; Straumann and Purves 2008). Landform units can be carried using various approaches, including automated mapping of landforms (MacMillan et al. 2000; Meybeck et al. 2001; Schmidt and Hewitt 2004; Saadat et al. 2008), classification of morphometric parameters, filter techniques, cluster analysis and multivariate statistics (Dikau 1989; Dikau et al. 1995; Adediran et al. 2004).

Geomorphometrics consist of geometry, topography, and physical landforms of the Earths horizons, over time, and branches out from the disciplines of geomorphology, geomatics and geomorphometry. It is a response to the development of this GIS technology to gather and 
process DEM data (e.g. remote sensing, the Landsat program and photogrammetry). Geomorphometry provides a quantitative description of the shapes of landforms. According to Blaszczynski (1997), landforms are defined as specific geomorphic features on the earth's surface, ranging from large-scale features such as plains and mountain ranges to minor features such as individual hills and valleys. Geomorphometric properties have been measured by calculating the geometry of the landscape manually (Horton 1945; Miller 1953; Coates 1958). Recently, advances in computer technology, increased processing power, new spatial analytical methods and the increasing availability of digital elevation data have reoriented geomorphometry (Pike 1999).

The aims of in the paper is preparing landform map based on Jennes algorithm in the salt dome of Korsia of Darab plain, Iran of Iran.

\section{Materials and methods}

The case areas were selected from ten different locations in salt dome of Korsia- Darab plain. The study area is located at $28^{\circ} 28^{\prime} 46^{\prime \prime} \mathrm{N}$ and $54^{\circ} 23^{\prime} 40^{\prime \prime} \mathrm{E}$, with area of $1083 \mathrm{~km}^{2}$. The locations of the case areas are shown in Fig. 1. Digital elevation models were include SRTM DEM (30 m resolution). The NASA shuttle radar topographic mission (SRTM) produced DEM with spatial resolution of $30 \mathrm{~m}$.

\section{Methods of classification}

The topographic position index (TPI) (Guisan et al. 1999) used in the study area. This method was further developed by Weiss (2001) and Jenness (2006). TPI (Eq. (1)) compares the elevation of each cell in a DEM to the mean
Fig. 1 Digital elevation mountain (DEM) of the study area

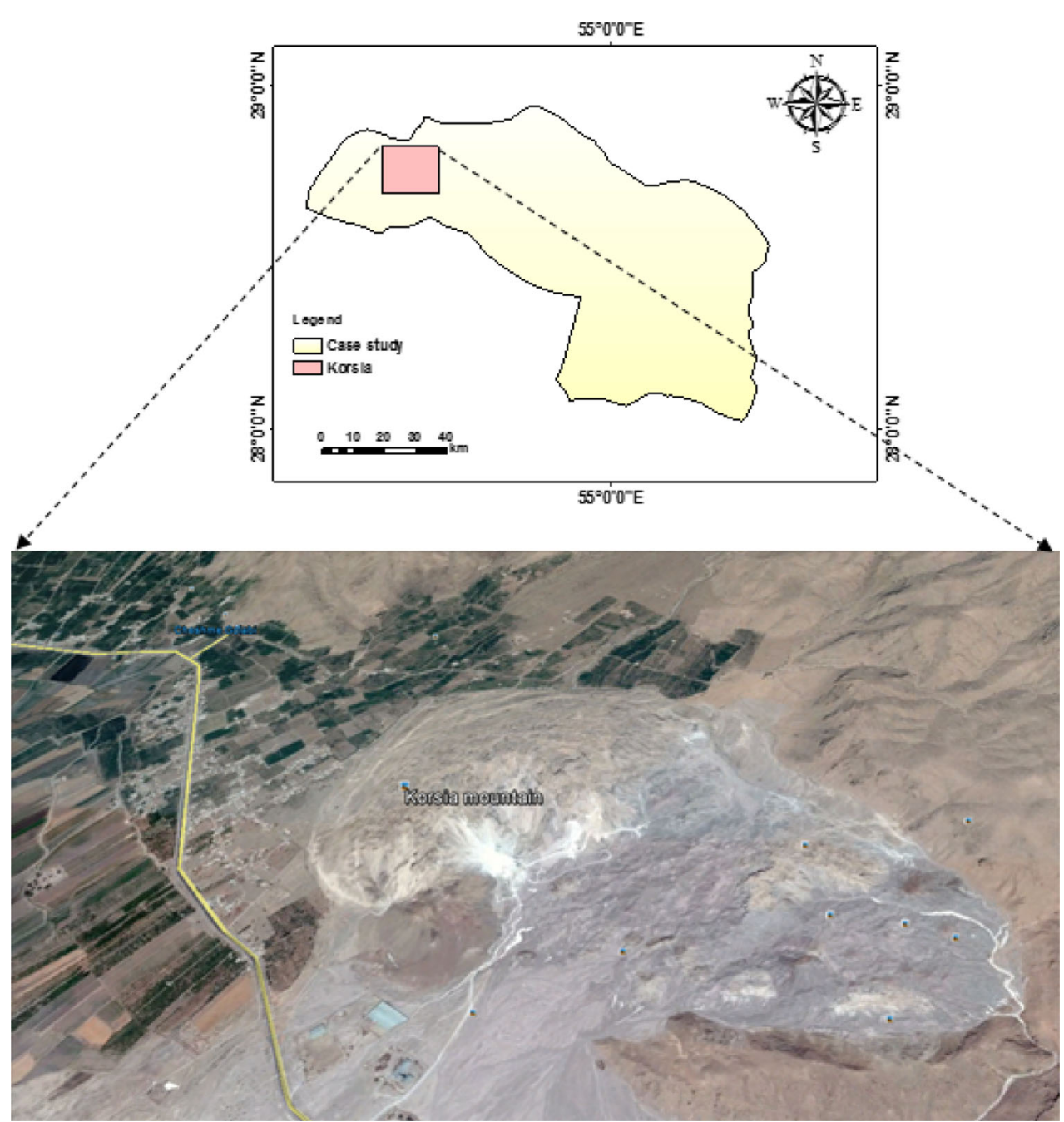



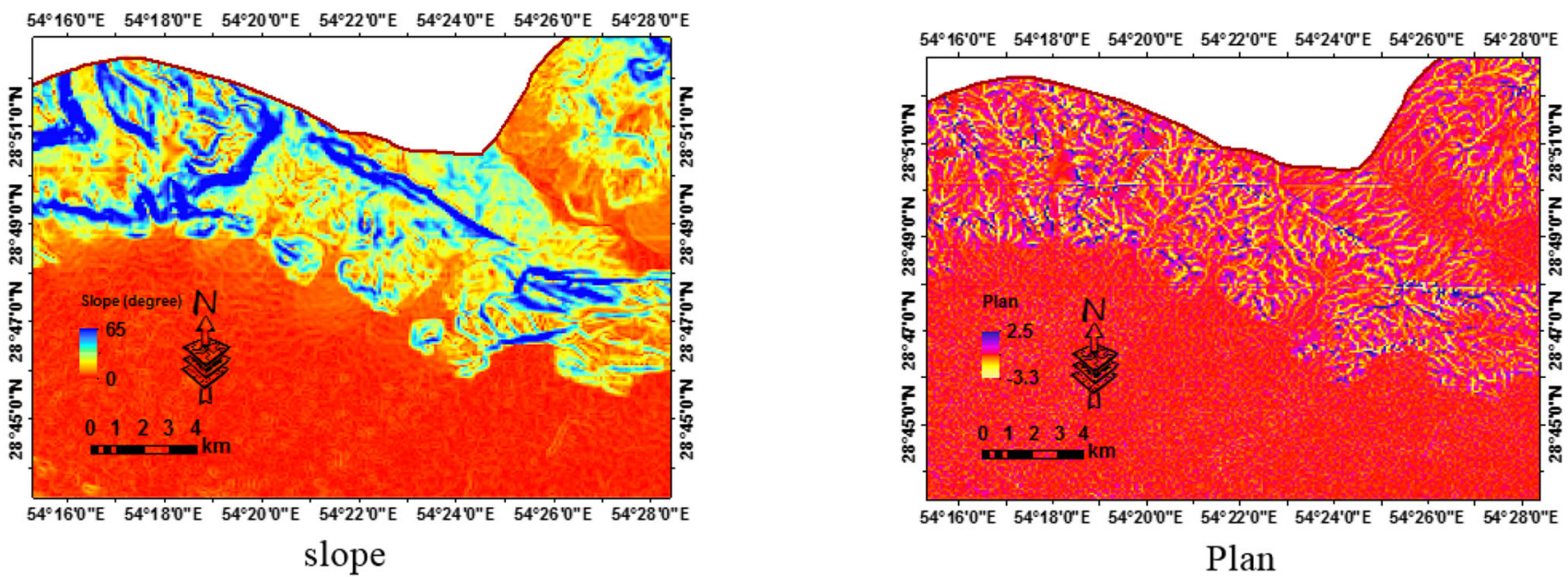

Plan
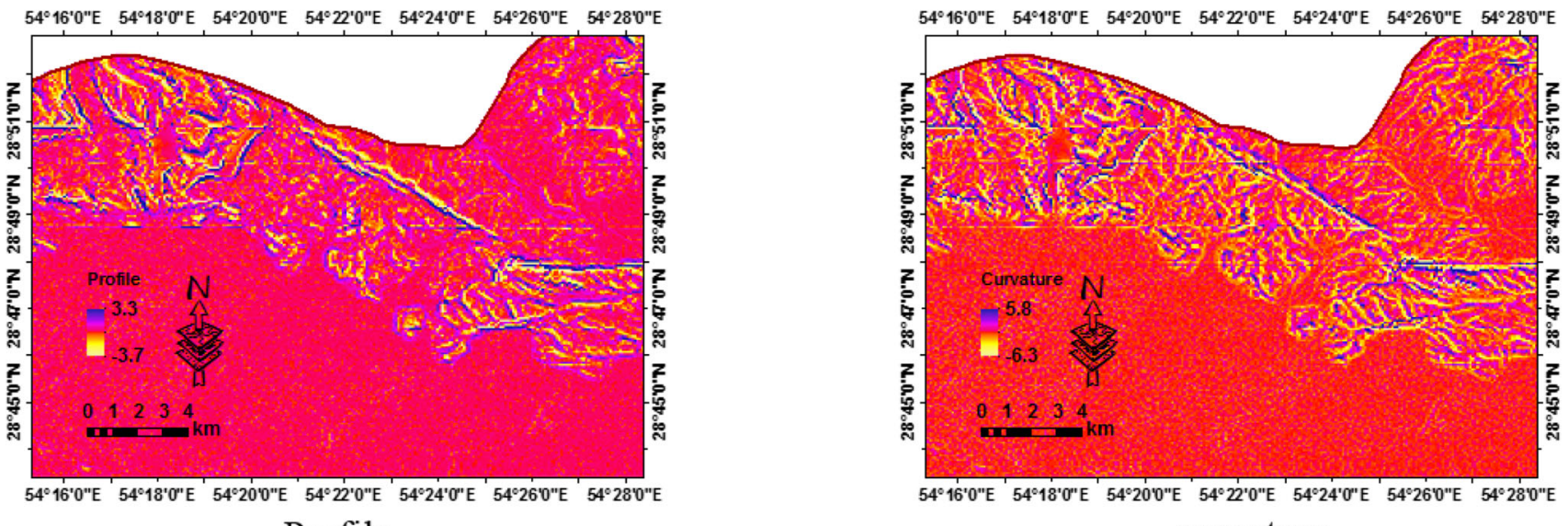

curvature

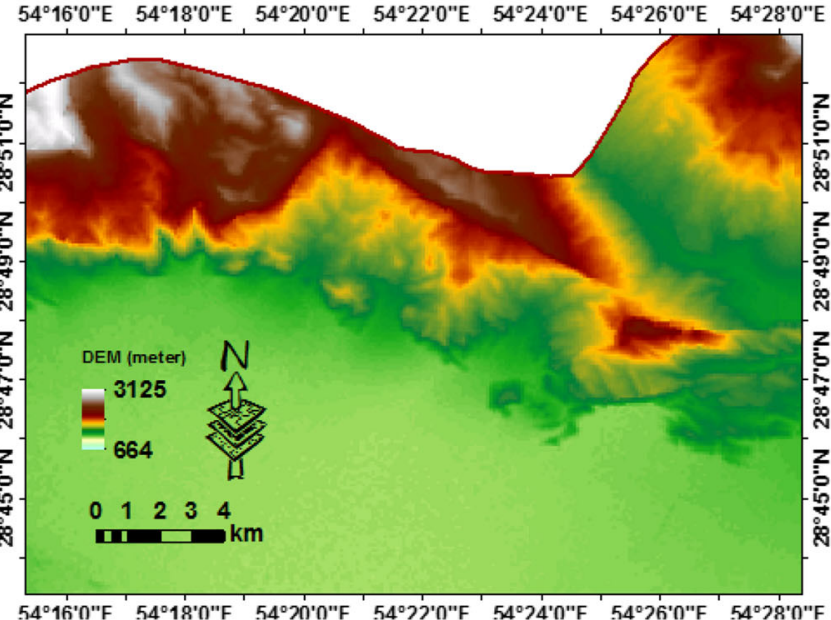

DEM

Fig. 2 Input data for landform classification 

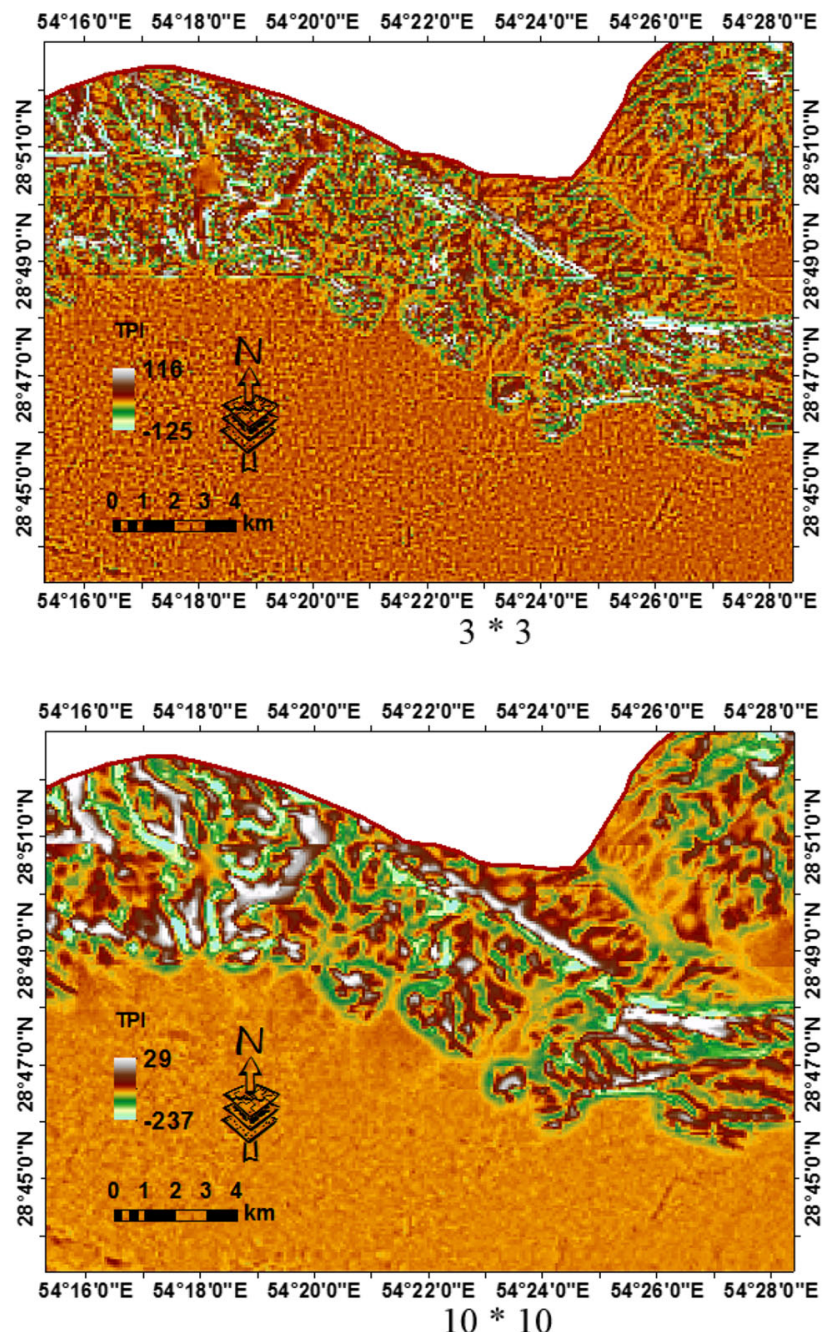

elevation of a specified neighborhood around that cell. Mean elevation is subtracted from the elevation value at center.

$T P I_{i}=M_{0}-\sum_{n-1} M_{n} / n$

where $M_{0}=$ elevation of the model point under evaluation, $M_{n}=$ elevation of grid, $n=$ the total number of surrounding points employed in the evaluation.

\section{Results}

Different values of input parameters (slope, curvature, plan, profile, elevation) (Fig. 2) used for preparing landform classification.

For landform classification via Jennes algorithm, first of all prepared TPI map for each cases that show in Fig. 3. According to Fig. 3, minimum and maximum TPI is -125 and +116 for scale of $3 * 3$ and -237 and +29 for scale of $10 * 10$.

After prepare TPI map for each of the cases study, the landform classification map were created (Fig. 4 and Table 1). Landform classification maps generated based on the computed TIP values are shown in Fig. 4. For this method, the classes consist of canyons/deeply incised

Table 1 Characteristics of the cases study

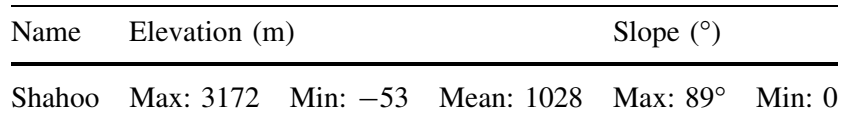

Fig. 3 TPI value for the study area

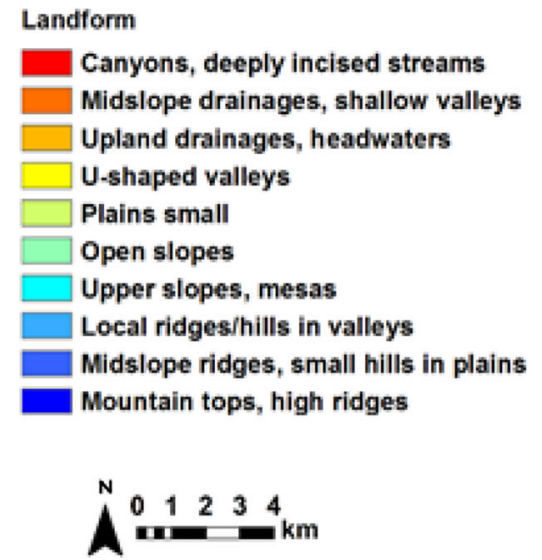

Fig. 4 Landform classification map

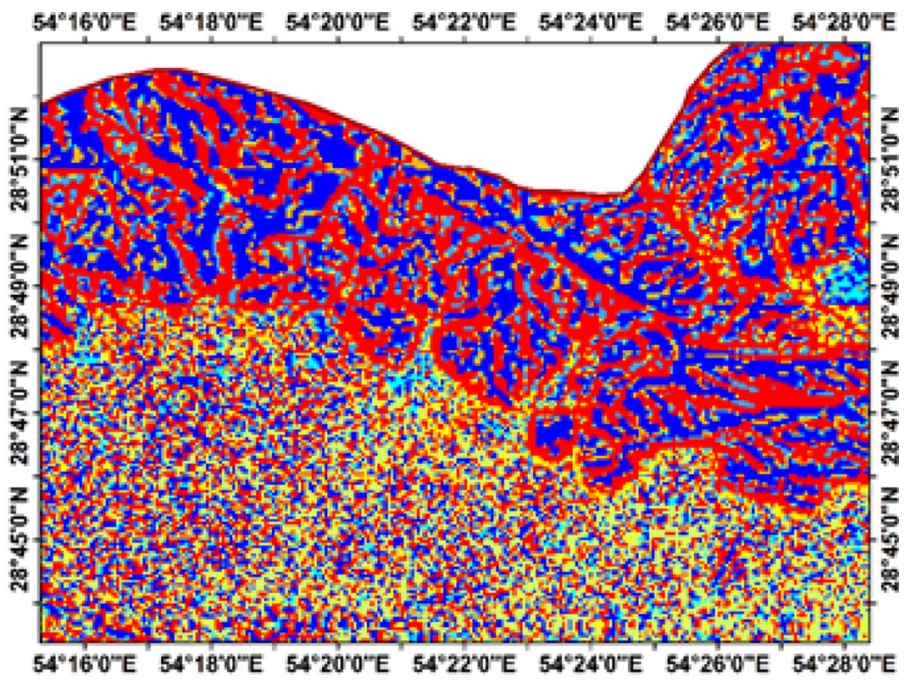


Table 2 Areas of features for the landform classification maps in Fig. 4

\begin{tabular}{lllr}
\hline Code & Classes & Area $(\%)$ & Area $\left(\mathrm{km}^{2}\right)$ \\
\hline 1 & Canyons, deeply incised streams & 35.22 & 114.62 \\
2 & Midslope drainages, shallow valleys & 1.90 & 6.17 \\
3 & Upland drainages, headwaters & 2.85 & 9.27 \\
4 & U-shaped valleys & 6.17 & 20.07 \\
5 & Plains small & 15.03 & 48.92 \\
6 & Open slopes & 0.19 & 0.61 \\
7 & Upper slopes, mesas & 3.13 & 10.18 \\
8 & Local ridges/hills in valleys & 4.10 & 13.33 \\
9 & Mid slope ridges, small hills in plains & 2.91 & 9.47 \\
10 & Mountain tops, high ridges & 28.51 & 92.77 \\
& Sum & 100 & 325.41 \\
\hline
\end{tabular}

Fig. 5 Area for each of classes

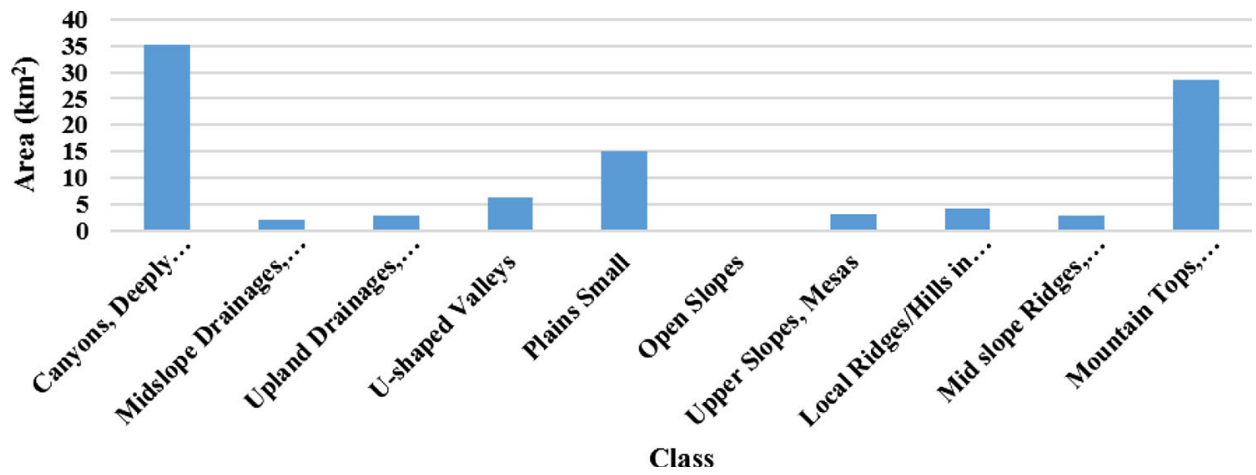

streams, midslope drainages/shallow valleys, upland drainages/headwaters, u-shaped valleys, plains small, open slopes, upper slopes/mesas, local ridges/hills in valleys, mid slope ridges/small hills in plains, mountain tops/high ridges.

The area for the each of classes show in Table 2 and Fig. 5.

For determination of landform type of dome of Korsia by Jennes method used 3 sample points that were shown in Fig. 6.

According to Fig. 6, mountain tops, high ridges was determined for dome of Korsia in the study area.

\section{Conclusions}

A landform is a natural feature of the Earth's surface. Landforms together make up a given terrain, and their arrangement on the landscape or the study of same is known as topography. Information on landforms are based on digital elevation models (DEM) and field studies. Method of Jennes is the most promising algorithm for classification of landforms. Also the results show that mountain tops, high ridges was determined for dome of Korsia in the study area. 


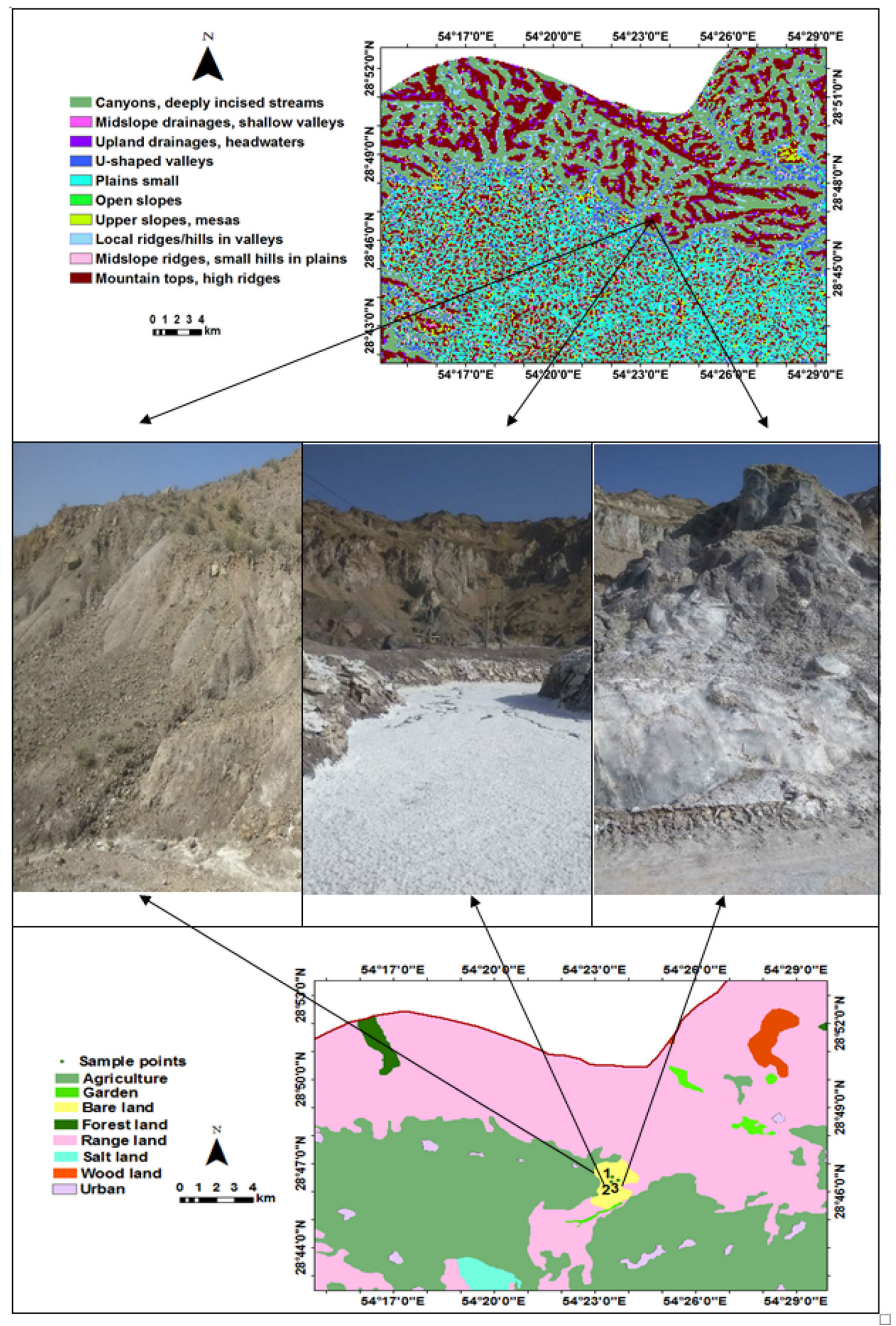

Fig. 6 Sample points of the salt dome of Korsia 


\section{References}

Adediran AO, Parcharidis I, Poscolieri M, Pavlopoulos K (2004) Computer-assisted discrimination of morphological units on north-central crete (Greece) by applying multivariate statistics to local relief gradients. Geomorphology 58:357-370

Barka I (2009) Remote sensing and GIS in geoecological research: a case study from Malá Fatra Mts., Slovakia In: Horák J, Halounová L, Kusendová D, Rapant P, Voženílek V (eds) Advances in geoinformation technologies. VŠB - Technical University of Ostrava, Ostrava, pp 77-88. ISBN 97880-2482145-0

Blaszczynski JS (1997) Landform characterization with geographic information systems. Photogramm Eng Remote Sens 63:183-191

Chorley RJ (1972) Chapter 1-spatial analysis in geomorphology. In: Chorley RJ (ed) Spatial analysis in geomorphology. Harper and Row Publishers, New York, pp 3-16

Coates DR (1958) Quantitative geomorphology of small drainage basins in Southern Indiana, 1st edn. Columbia University, New York

Dikau R (1989) The application of a digital relief model to landform analysis. In: Raper JF (ed) Three dimentional applications in geographic information sytems. Taylor and Francis, London, pp 51-77

Dikau R, Brabb EE, Mark RK, Pike RJ (1995) Morphometric landform analysis of New Mexico. Zeitschrift für Geomorphologie Supplementband 101:109-126

Evans IS (1972) Chapter 2-general geomorphometry, derivatives of altitude and descriptive statistics. In: Chorley RJ (ed) Spatial analysis in geomorphology. Harper and Row, Publishers, New York, pp 17-90

Guisan A, Weiss SB, Weiss AD (1999) GLM versus CCA spatial modeling of plant species distribution. Kluwer academic publishers. Plant Ecol 143:107-122
Horton RE (1945) Erosional development of streams and their drainage basins: hydrophysical approach to quantitative morphology. Geol Soc Am Bull 56:275-370

Jenness J (2006) Topographic Position Index (tpi_jen.avx) extension for ArcView 3.x, v. 1.3a. Jenness Enterprises. http://www. jennessent.com/arcview/tpi.htm

MacMillan RA, Pettapiece WW, Nolan SC, Goddard TW (2000) A generic procedure for automatically segmenting landforms into landform elements using DEMs, heuristic rules and fuzzy logic. Fuzzy Sets Syst 113:81-109

Meybeck M, Green P, Vorosmarty Ch (2001) A new typology for moutains and other relief classes. Moutain Res Dev 21(1):34-45

Mokarram M, Hojjati M, Roshan GH, Negahban S (2015) Modeling the behavior of Vegetation Indices in the salt dome of Korsia in North-East of Darab, Fars, Iran. Model Earth Syst Environ 1(3): $1-9$

Pike RJ (1999) A bibliography of geomorphometry, the quantitative representation of topography Supplement 3 (Open-File Report 99-140), US. Geological Survey

Ratajczak M, Jasiewicz J (2009) Application of free open-source software tools to automatic and semiautomatic classification of landforms in lowland areas. Geomorphol Slovaca et Bohem 9(1):43-52

Saadat H, Bonnell R, Sharifi F, Mehuys G, Namdar M, Ale-Ebrahim S (2008) Landform classification from a digital elevation model and satellite imagery. Geomorphology 100:453-464

Schmidt J, Hewitt A (2004) Fuzzy land element classification from DTMs based on geometry and terrain position. Geoderma 121:243-256

Straumann RK, Purves RS (2008) Delineation of valleys and valley floors. In: Cova TJ et al (eds) GIScience 2008, LNCS 5266. Springer, Berlin, pp 320-336

Weiss A (2001) Topographic position and landforms analysis. In: Poster presentation, ESRI user conference, San Diego, CA 